\title{
Condiciones de vida, conflicto y conciencia de clase en los horticultores del Gran La Plata, 1940-2003
}

\author{
Living conditions, conflict and class consciousness of horticulturists from \\ Gran La Plata, 1940-2003
}

Soledad Lemmi*

\begin{abstract}
Resumen: A partir del caso de los productores de hortalizas del Gran La Plata, este artículo se propone dar cuenta de la complejidad que envuelven, según la teoría marxista, los procesos de toma de conciencia, de develamiento del verdadero funcionamiento de las relaciones sociales en el capital, en las diferentes clases sociales. Presenta el contraste existente entre las condiciones de vida y de trabajo de los sujetos y la conciencia de esa situación, expresada a través del conflicto, intentando explicar si, a pesar de ser clases diferentes con respecto al capital, pueden ser homologadas en su conciencia.
\end{abstract}

Palabras clave: Argentina- horticultores- conflicto- conciencia-existencia- dialéctica

\begin{abstract}
From the case of horticulturists from Gran La Plata, this paper aims to account for the complexity involving, according to Marxist theory, the processes of awareness, of unveiling the real functioning of social relations in capital in different social classes. Presents the contrast between the conditions of life and work of individuals and the awareness of this situation, expressed through conflict, trying to explain whether, despite being different classes with respect to capital, may be approved in their consciousness.
\end{abstract}

Keywords: Argentina- horticulturist- conflict- consciousness- existence- dialectic

\footnotetext{
* Argentina. Profesora en Historia, Doctora en Ciencias Sociales y Humanas. Becaria Post Doctoral del Consejo Nacional de Investigaciones Científicas y Técnicas (CONICET). Integrante del Instituto de Investigaciones en Humanidades y Ciencias Sociales (IDIHCS-UNLP)- Consejo Nacional de Investigaciones Científicas y Técnicas (CONICET) y del Centro de Investigación sobre Economía y Sociedad de la Argentina Contemporánea (IESAC-UNQ). Correo: soledadlemmi@yahoo.com, lemmisoledad@gmail.com
} 


\section{Introducción}

"La historia de todas las sociedades que han existido hasta nuestros días es la historia de la lucha de clases", escribieron Marx y Engels en el Manifiesto Comunista en 1848 y esto, a pesar del tiempo transcurrido, no ha dejado de ser una verdad ${ }^{1}$. Aún cuando muchos científicos sociales profetizaron el fin de la clase obrera y de la historia con el triunfo de la burguesía, la tesis de Marx y Engels demostró toda su actualidad histórica. Los nuevos tiempos y las transformaciones producidas no modificaron el carácter capitalista de la sociedad y aunque en apariencia se han dado cambios en las clases que la componen, su esencia permaneció inalterada.

A partir de múltiples investigaciones, Marx llegó a una conclusión que fue expresada en su famoso Prólogo a la Contribución a la Crítica de la Economía Política (1859). Allí expuso que

En la producción social de su existencia, los hombres establecen determinadas relaciones, necesarias e independientes de su voluntad, relaciones de producción que corresponden a un determinado estadio evolutivo de sus fuerzas productivas materiales. La totalidad de esas relaciones de producción constituye la estructura económica de la sociedad, la base real sobre la cual se alza un edificio jurídico y político, y a la cual corresponden determinadas formas de conciencia social. El modo de producción de la vida material determina el proceso social, político e intelectual de la vida en general. No es la conciencia de los hombres lo que determina su ser, sino, por el contrario, su existencia social lo que determina su conciencia.

Sin embargo, unos párrafos después agregó nuevas variables a esa afirmación ya que esa expresión teórica, que aparecía como determinante y estática, debía complementarse con una mirada que distinguiera entre la transformación material de las condiciones económicas de producción y las formas jurídicas, políticas, religiosas, artísticas o filosóficas, en suma, ideológicas, dentro de las cuales los hombres cobran conciencia de ese conflicto y lo dirimen. Fue por ello que planteó que debía explicarse esa conciencia a partir de las contradicciones de la vida material, a partir del conflicto existente entre las fuerzas sociales productivas y las relaciones sociales de producción ${ }^{2}$.

En otros textos, anteriores y posteriores, desarrolló más ampliamente esa afirmación. Tanto en La ideología Alemana (1845), en Miseria de la Filosofía (1847) como en el 18 Brumario de Luis Bonaparte (1852) se encargó de desarrollar los diferentes estadios por los

\footnotetext{
${ }^{1}$ Carlos Marx y Federico Engels. Manifiesto del Partido Comunista (1848). (Buenos Aires: Edit. Anteo. 1997).

${ }^{2}$ Carlos Marx. Contribución a la Crítica de la Economía Política (1859). (México: Edit. Siglo XXI. 1990). Prólogo.
} 
que atraviesan las clases sociales y su conciencia de la situación que viven. En su obra más acabada, El Capital (1894), volvió a dedicarle un capítulo a este tema que finalmente quedó inconcluso. Otros teóricos hicieron sus agregados, Engels en su famosa Introducción a la Lucha de Clases en Francia de 1848 a 1850 (1895), Lenin en su libro ¿Qué hacer? Problemas candentes de nuestro movimiento (1902) y Gramsci en su escrito Análisis de las situaciones. Relaciones de fuerza (1932-34), profundizaron en la problemática de la toma de conciencia y sus estadios. Es entonces que, a partir de los postulados planteados por estos autores se propone en este artículo realizar un ejercicio de análisis empírico: analizar la dialéctica entre la existencia objetiva y la toma de conciencia de su situación en un conjunto humano vinculado en la producción, los horticultores del Gran La Plata en el período 1940-2003.

El cinturón hortícola platense surgió en 1880 con la fundación de la ciudad para abastecer a su población de alimentos frescos y la transformación desde sus inicios como producción para el autoabastecimiento familiar hasta la producción para ser vendida en el mercado llevó 60 años. Recién hacia la década del 40, junto al crecimiento demográfico que experimentó la Región Metropolitana de Buenos Aires (RMBA) de la mano de la industrialización, las huertas familiares se convirtieron en establecimientos hortícolas plenamente capitalistas. Los años 40 inauguraron un periodo de despegue de la producción mercantil capitalista y fue a partir de allí, y hasta mediados de los años 90, que se consolidó con fuerza la región platense como productora y abastecedora de hortalizas. Este desarrollo no se producirá sin altibajos, sin embargo, si se observa la tendencia general, el período puede caracterizarse como de ascenso y consolidación.

A partir de la década del 90 del siglo pasado los sujetos que llevaron adelante la producción hortícola en La Plata, sector más capitalizado del área hortícola bonaerense, aparecieron en la escena pública. En esos años, en los periódicos locales abundaban solicitadas, editoriales y notas que reflejaban el estado de movilización en que se encontraban. También fueron visibles en el paisaje urbano con la marcha de sus tractores y tomatazos a las instituciones gubernamentales, apareciendo en escena las organizaciones políticas y corporativas que nucleaban a los sujetos en conflicto. Surgía con evidencia que los cambios operados a nivel económico y político habían traído aparejados diferentes niveles de conflictividad y organización. Sus reclamos daban cuenta de una situación crítica para el sector en el marco de las políticas neoliberales. A su vez, para los habitantes del territorio platense, la presencia en aumento de gran cantidad de hectáreas con invernaderos que rodeaban la ciudad no escapó a sus ojos. Ni la presencia de un nuevo sujeto social que dominó casi por completo esa producción en los últimos años: el migrante boliviano.

En la actualidad, la RMBA por su importancia demográfica (13 millones de habitantes), presenta la mayor demanda en frutas y verduras del país. Su área hortícola abastece entre el 60 y el $90 \%$ de esa demanda, siendo el resto producido en regiones productivas 
especializadas. Específicamente, la producción del sector hortícola del Gran La Plata es responsable del $72 \%$ de ese abastecimiento ${ }^{3}$.

En la producción hortícola del Gran La Plata, aparecen claramente delimitadas las que son denominadas como "clases con respecto al capital", las clases en sí, poseedoras o no de medios de producción, trabajando para sí mismos o para otros, contratando o no fuerza de trabajo ${ }^{4}$. Sin embargo, la forma en las que se expresan las condiciones materiales de existencia en la vida de los sujetos de la horticultura es sumamente compleja. Cuando se contrastan las condiciones materiales de existencia con sus condiciones-calidad de vida y de trabajo y su conciencia de la situación, el resultado es llamativo. Aquellos que poseen los medios de producción no necesariamente viven mejor que los trabajadores asalariados. $\mathrm{Ni}$ el hecho de vivir de la misma manera, en relación a la calidad de vida, los lleva a una unificación en la conciencia de su situación.

Es sobre este último punto que se quiere dar cuenta en este artículo, presentar las condiciones-calidad de vida de los sujetos (acceso a vivienda, servicios, educación, salud, etc.), sus condiciones laborales y contrastarlas con su conciencia de esa situación expresada a través del conflicto, ya que allí es donde pueden observarse las contradicciones más llamativas. Dilucidar si, a pesar de ser clases diferentes con respecto al capital, pueden ser homologadas en sus intereses a partir de compartir similares condiciones-calidad de vida y de lo que expresan en los enfrentamientos. Con esta pesquisa se propone dar cuenta de la complejidad que, según la teoría marxista, envuelve los procesos de toma de conciencia, de develamiento del verdadero funcionamiento de las relaciones sociales en el capital ${ }^{5}$.

Para ello se aborda la composición social del sector productivo hortícola platense concentrando la atención en cuáles son las reivindicaciones que las diferentes clases que lo componen llevan adelante, qué conciencia expresan, en qué momento de su constitución se encuentran, cuál es su respuesta política a las dificultades para reproducirse, cuál es el límite máximo alcanzado por las clases o fracciones de clase más empobrecidas en el proyecto de transformación social en un sentido superador de las relaciones sociales capitalistas, qué elementos de ese espacio social han sido transformados y cuáles se mantienen. Este marco teórico entiende que el enfrentamiento no se da clase contra clase, sino a través de alianzas sociales tras un objetivo común que constituyen fuerzas sociales en pugna. Partiendo de esta perspectiva se pretende observar la capacidad del sector bajo estudio de realizar alianzas con otras clases o fracciones de clase, para así efectuar un aporte al estudio más general de la conformación de fuerzas sociales en la Argentina. Esto

\footnotetext{
${ }^{3}$ Matías García, "Inicios, consolidación y diferenciación de la horticultura platense". Globalización y agricultura periurbana en la Argentina. Escenarios, recorridos y problemas. Ada Svetlitza de Nemirovsky (coord.). (Bs. As.: Edit. FLACSO, 2010).

${ }^{4}$ Soledad Lemmi, "Las clases sociales en la horticultura platense. Ejercicio de teorización, historización y análisis empírico", Mundo Agrario, Revista de Estudios Rurales, Vol: 12 No. 23 (2011).

${ }^{5}$ Carlos Marx, Miseria de la Filosofía (Bs. As.: Edit. Cartago, 1987). Marx, Contribución.
} 
es estudiado a partir de lo que se denominan enfrentamientos, es decir cada vez que un sujeto del sector se manifiesta a favor o en contra de otro sujeto (del sector o no). A su vez se estudian las diferentes formas organizativas que estas clases se dan para llevar adelante sus reivindicaciones. El enfrentamiento se convierte en el eje heurístico privilegiado para observar la formación de las clases sociales, en tanto éstas se conforman a partir de la confrontación y la lucha, pudiendo a partir de allí historizar su devenir .

A la hora de observar la producción de hortalizas puede decirse que la misma está dominada por relaciones sociales de tipo capitalista ${ }^{7}$. Si bien se han sucedido cambios a lo largo de su existencia, en el sector han predominado las relaciones clásicas del capitalismo: posesión privada de la propiedad, en este caso la fundamental: la tierra; en general aunque no siempre trabajada por sujetos no propietarios; las relaciones asalariadas en la compraventa de la fuerza de trabajo; la extracción y apropiación de la plusvalía; la producción de mercancías para ser vendidas en el mercado y la reinversión productiva de la riqueza ${ }^{8}$. Es por ello que los sujetos que componen la producción de hortalizas no son más ni menos que las clases sociales inmersas en y condicionadas por las relaciones sociales capitalistas. Así, cuando observamos a los sujetos en conflicto vemos, por un lado, los terratenientes poseedores de la tierra; la burguesía dueña de los medios de producción y del capital, y los trabajadores asalariados, quienes llegan a la producción sin ninguna otra posesión que su fuerza de trabajo, dispuestos a venderla al mejor postor ${ }^{9}$. Sin embargo, esta división no es más que una abstracción teórica, mientras que la realidad es siempre más compleja y heterogénea, por lo que se encuentra esta división matizada de diferentes formas, pudiendo encontrar hacia dentro de la fracción productora de hortalizas estratificaciones internas, es decir capas. Estas capas se distinguen por las condiciones en que reproducen su vida, delimitando hacia adentro capas más acomodadas y capas más pobres.

Sin embargo, puede decirse que la toma de conciencia del lugar que cada uno ocupa en la producción y de la relación que a partir de allí se establece con la totalidad social es un proceso de aprendizaje que lleva tiempo. Proceso en parte espontáneo que brota de la lucha misma y que es ya un embrión de la acción consciente, pero también en parte mediado por otros sujetos que viviendo los hechos los analizan a la luz del presente y de su pasado, buscando explicaciones y teorizando acerca de ellos, superando la "espontaneidad" inicial y retransmitiendo, en tanto cuadros políticos e intelectuales orgánicos, estos conocimientos a los sujetos en lucha, generando procesos de toma de conciencia. Este proceso atraviesa diferentes momentos o estadios, momentos que son determinados por la historia de las

\footnotetext{
${ }^{6}$ Nicolás Iñigo Carrera, La estrategia de la clase obrera 1936 (Bs. As.: Edit. La Rosa Blindada-PIMSA, 2004), 13-28. Inés Izaguirre, "Algunos ejes teórico-metodológico en el estudio del conflicto social" Revista Argumentos, Vol: 1 (2002). Edward Thompson, La formación de la clase obrera en Inglaterra (Barcelona: Edit. Crítica, 1989). Prólogo.

${ }^{7}$ Lemmi, Las clases sociales.

${ }^{8}$ Ismael Viñas, Tierra y clase obrera. (Bs. As: Edit. Achával Solo, 1973).

${ }^{9}$ Carlos Marx, Trabajo asalariado y capital. Salario, precio y ganancia. (Bs. As.: Edit. Polémica, 1974).
} 
luchas mismas. A través de ellas las clases van pasando de una conciencia puramente económica, a una económico-corporativa, a una conciencia política para arribar finalmente a su mayor estadio, el momento militar. Estas etapas son etapas de la lucha, del enfrentamiento y como tales manifestaciones del momento por el que atraviesa la conciencia de los sujetos y de su constitución en tanto clase ${ }^{10}$.

Dado el marco teórico propuesto, se buscaron todas aquellas fuentes de información donde se manifestara de alguna manera un sujeto del sector hortícola contra otro sujeto, cualquiera fuera este. De acuerdo con la complejidad del tema el diseño metodológico combinó procedimientos cuantitativos y cualitativos, y constó de relevamiento de información primaria y secundaria. Se partió entonces del registro de los periódicos locales "El Día" y "Hoy" desde 1990 y a partir de los datos encontrados se comenzó el rastreo de información que diera cuenta de la historia de las organizaciones políticas y gremiales que se manifestaban en el conflicto. Para pasar a este segundo plano, se acudió a los archivos documentales guardados por instituciones estatales como el archivo y biblioteca del Senado de la Provincia de Buenos Aires, del Departamento Histórico Judicial de la Suprema Corte de Justicia de la Provincia de Buenos Aires y de la Secretaría de Acción Cooperativa de la Provincia de Buenos Aires.

A su vez, al aparecer en escena diferentes organizaciones gremiales y políticas se las fue desagregando y buscándose para cada una los datos concretos consultando archivos, documentos y periódicos de las propias organizaciones. Para ello también se consultaron los materiales del Archivos de la Dirección de Inteligencia de la Provincia de Buenos Aires (DIPBA) y del Centro de Documentación e Investigación de la Cultura de Izquierdas en la Argentina (CEDInCI). Debieron consultarse también documentos en el Departamento de Investigación Histórica y Cartográfica de la Dirección de Geodesia dependiente del Ministerio de Infraestructura de la provincia de Buenos Aires, como así también los Censos Hortícolas de la provincia de Buenos Aires de 1998 y 2001 y Hortiflorícola de 2005. A su vez, se intentó avanzar en la comprensión de los aspectos subjetivos que motivan la participación o no, en organizaciones u acciones de tipo gremial y político, así como triangular información y poder arribar a nuevos datos o elementos quizás no perceptibles en otras fuentes. Para ello se profundizó el diálogo a partir de entrevistas en profundidad realizadas entre los años 2008 y 2011, con el objetivo de dar cuenta de los aspectos vinculados a las trayectorias de vida y a elementos sujetivos no ponderables desde la acción misma. A su vez, a partir de las entrevistas y del trabajo de campo realizado pudo observarse la forma de vivir de los diferentes sujetos de la horticultura. En todos los casos se analizaron también fuentes secundarias, básicamente escritos realizados por otros

\footnotetext{
${ }^{10}$ Marx y Engels, Manifiesto. Alberto Pla, "Trabajo productivo y trabajo improductivo, clases sociales y capitalismo", Anuario de la Escuela de Historia de la Universidad Nacional de Rosario Vol: 11 (1985). Alberto Pla, "Apuntes para una discusión metodológica. Clases sociales o sectores populares. Pertinencia de las categorías analíticas de "clase social' y 'clase obrera", Anuario de la Escuela de Historia de la Universidad Nacional de Rosario Vol: 14 (1989/90).
} 
investigadores que fueron de gran ayuda para el fortalecimiento del análisis y la argumentación.

Este trabajo se divide en tres partes. Se inicia con la descripción de las condiciones materiales de existencia de los sujetos horticultores, es decir cómo viven, para pasar a una segunda parte donde se desarrollan los resultados del enfrentamiento y observar a partir de la lucha como actúan. Luego se intenta analizar la dialéctica existente entre ambas instancias, materialidad y acción, para arribar a una posible explicación de cómo piensan, es decir de su conciencia de la situación que viven. Finalmente se desarrollan algunas conclusiones ${ }^{11}$.

\section{Condiciones de vida y conflicto (cómo viven, cómo actúan, cómo piensan)}

\section{Como viven}

La consolidación del territorio hortícola platense se concretó a partir de mediados del siglo $\mathrm{XX}$. Fue entre fines de los años 40 y mediados de los años 60 que muchos de los trabajadores migrantes hortícolas (aunque claramente no todos) lograron pasar de peones y peones medieros subiendo un peldaño en la escalera de ascenso social: se convirtieron en patrones y/o propietarios, alcanzando a arrendar o comprar la tierra ${ }^{12}$. Gracias a la forma particular que adoptó la contratación de mano de obra en la horticultura, por pago a destajo o por productividad, que fuera denominada como "mediería" aunque objetivamente no cumpliera ese requisito, y la posibilidad que ello conllevó de ocupar toda la mano de obra familiar en la tarea, los trabajadores pudieron obtener márgenes de ahorro que, en determinadas situaciones, les permitieron el acceso a la tierra en forma de arriendo y finalmente compra.

En la realidad, lo que suele denominarse "mediería" señala la particularidad que poseen los trabajadores asalariados, es decir desposeídos de sus condiciones materiales de existencia, que venden su fuerza de trabajo de manera colectiva, es decir a través del núcleo familiar completo pagándose la misma a destajo. Tanto las mujeres como los niños, es decir todos los individuos de la familia obrera rural, se convierten en trabajadores bajo la dependencia

\footnotetext{
${ }^{11}$ Este artículo representa un resumen de mi tesis doctoral titulada "Vivir como peón, pensar como patrón. Conflicto, organización política y conciencia de clase en el sector hortícola del Gran La Plata (1953-2009)", por la que obtuve el título de Doctora en Ciencias Sociales y Humanas otorgado por la Universidad Nacional de Quilmes.

${ }^{12}$ Roberto Benencia. "El concepto de movilidad social en los estudios rurales", Estudios Rurales. Teorías, problemas y estrategias metodológicas. Giarraca, Norma (coord.) (Buenos Aires: Edit. La Colmena. 1999). Silvia Attademo, "Cambios en las condiciones de vida de los horticultores en la región subrural del Gran La Plata a fines de siglo". XXII Encuentro de la Latin American Studies Association (2000). Silvia Attademo, "Lazos sociales y estrategias: ¿una opción para las familias hortícolas empobrecidas?". Revista Mundo Agrario No. 17 (2008).
} 
inmediata del capital ${ }^{13}$. El varón dentro del núcleo familiar toma las decisiones en relación a la producción determinando los roles de la mujer y los niños, en tanto los ingresos de la familia se componen de la cantidad de trabajo suministrada por el jefe de familia y se acrecientan con el trabajo del resto de los miembros de la misma. En este caso lo que le interesa al trabajador es la cantidad de dinero que recibe, es decir el monto nominal, no lo que entrega, es decir la cantidad de trabajo ${ }^{14}$. En este sentido pacta trabajo a destajo determinando su salario en función de la cantidad de mercancías producidas y efectivamente vendidas, es decir un porcentaje de la producción. Los peones medieros en ocasiones cumplen la función de representar al capital en el proceso de trabajo, actuando como guardianes de la producción, como si fueran propietarios, con la asignación del poder que le otorga el patrón para contratar o despedir a otros trabajadores, supervisando la realización de las tareas en tiempo y forma.

Pero estos trabajadores medieros no aportan parte del capital de explotación, no son poseedores de una parte de los instrumentos de trabajo ni son "capitalistas de sí mismos"15. Muy por el contrario ingresan a la producción sólo con su fuerza de trabajo y se les pagará en función de la cantidad de productos en que se condensa el trabajo durante un tiempo determinado, es decir a destajo. Como la calidad e intensidad del trabajo están controladas por la forma misma del salario, ésta vuelve superflua gran parte de la vigilancia del trabajo. Permite también al capitalista pactar con el obrero principal un contrato a razón de tanto por pieza, a un precio por el cual el obrero principal mismo se encarga de contratar y pagar a sus auxiliares. La explotación de los obreros por el capital se lleva a cabo aquí mediante la explotación del obrero por el obrero, además de que es su interés emplear su propia fuerza de trabajo de la manera más intensa posible. Pero el mayor campo de acción que el pago a destajo ofrece a la individualidad, tiende por una parte a desarrollar dicha individualidad y con ella el sentimiento de libertad, la independencia y el autocontrol de los obreros, y por otra parte la competencia entre ellos mismos, de unos contra otros. Tiende, pues, a aumentar los salarios individuales por encima del nivel medio y, al mismo tiempo, a abatir ese nivel, sirve de palanca para prolongar la jornada laboral y hundir el salario. El obrero toma en serio la apariencia del pago a destajo, como si se le pagara su producto y no su fuerza de trabajo, y se rebela por tanto contra una rebaja de salarios a la que no corresponde una rebaja en el precio de venta de la mercancía, vigilando celosamente el precio de la materia prima y el precio de los artículos fabricados, estimando con precisión las ganancias de sus patrones ${ }^{16}$. En la horticultura platense fue gracias a esta forma particular que adquirió el trabajo que los peones medieros pudieron ascender socialmente.

\footnotetext{
${ }^{13}$ Nicolás Iñigo Carrera, "El concepto de clase obrera", Labour Again. Debates. Internacional Institute of Social History (2003).

${ }^{14}$ Carlos Marx, El Capital. (Buenos Aires: Edit. Siglo XXI, 2003). Cap. 18.

${ }^{15}$ Marx, El Capital, cap. 47.

${ }^{16}$ Marx, El Capital, cap. 19.
} 
Para la mayoría de los sujetos entrevistados, el ascenso de peón mediero al status de patrón productor y propietario fue por vía del arrendamiento. Mediante el mismo se logró en aquellos tiempos un rápido proceso de acumulación, el cual en no más de 5 años les permitió el acceso a la propiedad de tierras. La superficie arrendada y la adquirida rondaba entre las 4 y las 7 has, lo que permitió, en un principio, que trabajara toda la familia. Paralelamente, la ampliación familiar y la generación de nuevos matrimonios en muchos casos con miembros de otras familias de la zona que también eran productores de hortalizas, reforzaba la presencia de esta comunidad en la actividad y la región.

En los años '50, la producción hortícola se caracterizó por el trabajo a campo descubierto, una labranza de la tierra con los "arados mancera" tirados por caballos, mientras que la refinación posterior se realizaba en forma manual con palas y azadas, las plagas y enfermedades intentaban controlarse con extracto de nicotina (tras el remojo de cigarrillos en agua) y con caldo bordelés (sulfato de cobre), la fertilización también era orgánica, utilizándose grandes cantidades de bosta de vaca ${ }^{17}$. Si se tiene en cuenta que todavía existían tierras disponible, las posibilidades de trabajar el núcleo familiar completo, los bajos costos de los medios de producción, los precios de las hortalizas elevados y la baja competencia, todo esto permitió obtener mayores ganancias y por lo tanto un mayor poder de ahorro e inversión en compra de tierras, agregado a ello también las políticas estatales facilitadoras ${ }^{18}$.

A partir de 1960, comenzaron a afluir a las quintas locales trabajadores provenientes de las provincias del norte del país, principalmente santiagueños, seguidos por salteños y jujeños. Fueron en un principio jornaleros con pago diario, semanal o quincenal, o tanteros con retribución por producción, dedicándose a tareas de encañe, desbrote, cosecha y embalaje. $\mathrm{Al}$ igual que los migrantes de ultramar, en sus lugares de origen practicaban la agricultura de subsistencia. Estos trabajadores fueron contratados por los europeos y sus descendientes, ahora devenidos en patrones productores. Un porcentaje de estos migrantes del Norte argentino quedó establecido en la zona, en ocasiones trabajando en relación de mediería y repitiendo la escalera de ascenso social comenzada por los "gringos"19. Sin embargo, la mayoría en la época efectuó una migración estacional ${ }^{20}$.

\footnotetext{
${ }^{17}$ Roberto Ringuelet comp. Espacio tecnológico, población y reproducción social en el sector hortícola de La Plata. Revista No.39. (Bs. As: UNLP, 2000).

${ }^{18}$ Soledad Lemmi, "La institucionalización del conflicto en la horticultura platense. Un registro de los juicios en Tribunales del Trabajo en las décadas del 60 y 70". El conflicto agrario argentino. Sujetos, miradas y reflexiones. José Muzlera, Marina Poggi y Ximena Carreras Doallo (comp.) (Buenos Aires: Edit. CICCUS. 2011).

${ }^{19}$ En Argentina, la palabra gringo hace referencia, por lo general, a las personas de tez blanca y/o cabellos claros, sin importar la procedencia de ésta. En el caso del territorio platense, era y sigue siendo utilizada para indicar la nacionalidad o descendencia italiana.

${ }^{20}$ Ringuelet comp., Espacio.
} 
Puede observarse cómo en un período que abarca poco más de 30 años aproximadamente, muchos de los migrantes europeos pasaron de ser peones a peones medieros, para luego llegar a ser patrones productores ya sea bajo la figura de arrendatarios o propietarios, hasta finalmente convertirse en patrones productores que ya no aportaban trabajo físico en la quinta, cumpliendo sólo una función gerencial.

Sobre fines de los años ' 70 y principios de los años ' 80 comenzaron a arribar a la zona en busca de trabajo en la horticultura migrantes de Bolivia. Empezaron como peones de los patrones productores italianos y sus descendientes y se fueron consolidando de a poco junto al trabajo de toda su familia como peones medieros. Tal como medio siglo antes habían llegado los migrantes italianos, los migrantes bolivianos arribaron al trabajo acompañados de todo el núcleo familiar, y si bien en un contexto diferente, muchos lograron emprender su camino de ascenso social, subiendo los peldaños de la escalera construida por los pioneros italianos ${ }^{21}$.

Consolidada la producción hortícola en el periurbano platense, esta adquirió una nueva dinámica a partir de mediados de la década del ' 80 y principalmente durante los ' 90 ya que comenzaron a impulsarse profundas transformaciones tecnológicas. En forma gradual, la espiral tecnológica que comenzó en los '70 incluyó la mecanización, agroquímicos, híbridos, riego localizado, fertirrigación, y la incorporación del invernadero o superficie bajo cubierta teniendo grandes repercusiones en los rendimientos, la calidad de la producción, la demanda de insumos, la comercialización y la utilización y remuneración de los distintos factores de producción ${ }^{22}$. Esto da cuenta también de la creciente complejización de los procesos productivos y de la inversión en tecnología innovadora, dos elementos que manifestaron el continuo avance del capitalismo en el sector.

Esta etapa expansiva fue llevada adelante por los dos sujetos predominantes en la horticultura, los descendientes de los inmigrantes italianos y los recientemente llegados de Bolivia $^{23}$. En su rol de patrones productores (propietarios o arrendatarios, patrones y directores de la producción) así como, en una primera instancia, también hegemónicos en los procesos de comercialización, la segunda y tercera generación de hijos de inmigrantes ultramarinos fueron los encargados de invertir y gestionar las nuevas tecnologías. En cambio, los migrantes recientes aportaron casi en su totalidad la fuerza de trabajo como peones medieros, trabajando toda la familia para poder hacer la diferencia y obtener márgenes de ahorro, restringiendo para lograrlo, al igual que los inmigrantes en sus orígenes, los gastos personales.

Las nuevas condiciones que exigía la producción, tanto en capital para la inversión de tecnologías como en las nuevas lógicas de comercialización, llevó a que un sector

\footnotetext{
${ }^{21}$ Entrevistados 32 a 46.

${ }^{22}$ Mario Vega., "Integración vertical y productos diferenciados", Boletín Hortícola, No. 23 (1999) 33-35.

${ }^{23}$ Los entrevistados 32 a 46 dieron testimonio de esta situación. Así como los entrevistados 2, 4 a 7, 13 a 16, 20 y 29 a 31 .
} 
importante de patrones productores no pudieran afrontarlas desde sus escalas de producción y sus niveles de acumulación. Fue así que a pesar de poseer la propiedad, terminaron endeudados con organismos de crédito, no pudiendo renovar los medios de producción, o sin poder hacer frente a los acreedores. Una vez que habían ascendido en la escala social habiendo pasado por todos los peldaños de la escalera, los descendientes de italianos no estuvieron dispuestos a retraer el consumo o descender en su nivel de vida como lo habían realizado sus abuelos y padres y lo realizaban los migrantes bolivianos. Frente a esa posibilidad algunos vendieron la tierra, abandonando la producción y dedicándose a otros trabajos. En ocasiones como asalariados en labores relativamente bien pagas o en mejores condiciones que la horticultura, en otras emprendiendo nuevas actividades de comercialización como sólo la venta de verdura en el mercado, o en verdulerías u otros comercios propios. Otros mantuvieron la tierra pero ya no la trabajaron. Por diferentes motivos, aunque muchos de ellos por falta de descendientes que quisieran seguir en la producción, decidieron arrendar las hectáreas que poseían pasando de patrones productores a terratenientes o a gestionarlas con peones medieros ${ }^{24}$.

Los migrantes bolivianos que habían llegado como peones, para luego ser peones medieros y, sobre todo post-crisis del 2001, como patrones productores en base al arriendo de tierras, no pudieron alcanzar el peldaño de la posesión de la misma. Si bien para los horticultores que llegaron al país promediando los años ' 40 el acceso a la tierra fue relativamente posible, no fue tan sencillo para los migrantes recientes. Las inversiones en tecnología que requería una quinta para la producción eran muy costosas, teniendo que disponer en una primera instancia de una suma de capital para comprar invernáculos, instalar riego, comprar o alquilar el tractor, etc. y en el caso de los que comercializaban su propia verdura la necesidad de vehículos para llegar hasta el mercado. Esto llevó a que no pudieran disponer de un excedente suficiente para, además de afrontar todos los gastos de producción, invertir en la compra de tierras, lo que implicaba inmovilizar importantes sumas de capital. Se sumó a esto la especulación inmobiliaria que llevó los precios de la tierra a niveles altísimos, muchas veces inaccesibles para los arrendatarios ${ }^{25}$.

En la medida que los sujetos de la horticultura fueron ascendiendo socialmente también fueron cambiando sus condiciones de vida, sin embargo este cambio importante en algunos aspectos, no fue radicalmente profundo en otros. Se quiere expresar con esto que si bien algunos pudieron acceder a la posesión de los medios de producción este hecho no

\footnotetext{
${ }^{24}$ Entrevistados 1 y 2, 4, 6, 13 al 16, 18 y19, 21 y 22, 30 y 31. María Alejandra Waisman y María Florencia Rispoli, "Sembrando al sol. Algunas consideraciones antropológicas sobre el trabajo hortícola", $V$ Jornadas de Sociología de la Universidad Nacional de La Plata (2008). María Alejandra Waisman, María Florencia Rispoli y Silvia Attademo, "Expectativas, opciones y proyectos: la dimensión subjetiva en la elección laboral de horticultores platenses", IX Congreso Argentino de Antropología Social "Fronteras de la Antropología" (2009). María Alejandra Waisman, "El debate sobre la persistencia de la producción familiar y sus implicancias en el abordaje de la horticultura", VI Jornadas de Sociología de la Universidad Nacional de La Plata (2010).

${ }^{25}$ Entrevistados 32, 34 a 46.
} 
modificó radicalmente su calidad de vida. Es importante remarcar que en relación a las condiciones de vida, la situación de migrantes de los trabajadores influyó de manera profunda en esta cuestión. Los primeros trabajadores de la horticultura, migrantes europeos, comenzaron viviendo en las mismas condiciones en que lo hicieron más recientemente los migrantes bolivianos. Pero en la medida que ascendieron socialmente se observa que ambos sujetos (migrantes europeos y migrantes latinoamericanos) hicieron trayectos diferentes. Existe un importante corpus académico respecto de las trayectorias que los migrantes bolivianos han llevado adelante ${ }^{26}$, sin embargo no se han investigado comparativamente las trayectorias de ambos sujetos, ni si realmente dichos trayectos fueron muy disímiles y en qué medida los contextos históricos habilitaron condiciones de posibilidad muy diferentes para ambos. Por dicho motivo se intenta realizar aquí este ejercicio comparativo.

Uno de los elementos que mejor ayuda a delimitar las condiciones de vida es la vivienda. Historizando este aspecto se observa que desde los orígenes los sujetos de la horticultura tendieron a vivir en las explotaciones. Los trabajadores (peones medieros o no) vivieron efectivamente allí dado que el trabajo que demandaba la producción de hortalizas era permanente. Más recientemente, las viviendas de los migrantes bolivianos (sean estos patrones productores o peones medieros) son muy precarias, construidas con maderas y chapas, en formato de casillas desmontables con poca iluminación y ventilación. Estas casillas no cuentan con baño adentro, sino que la mayoría de las veces se encuentra fuera de la casa. Tienden a no tener inodoros, sino pozos tipo letrinas. No es regular la provisión de agua potable dentro de la casa, aunque la mayoría posee una canilla fuera para abastecerse. No poseen gas natural sino en garrafas. Rara vez se encuentran hornos sino más bien cocinas con hornallas. Poseen luz, pero las instalaciones son muy precarias, cables colgando con culotes y bombitas. Las aberturas también son precarias, en general las puertas y ventanas se cubren con cortinas, no siempre poseen vidrios y sí postigos de madera. El piso es de tierra.

Obviamente, estos elementos deben ser matizados ya que algunas viviendas poseen piso alisado de cemento pero sin baño, otras, agua potable dentro de la casa, pero no piso de cemento, etc. La calefacción es muy deficiente, siendo muchas veces el motivo de incendio de las casillas con las consecuentes pérdidas materiales. Se desprende que los niveles de intimidad son casi nulos. En esta primera instancia la vestimenta es precaria, ya que toda la ropa es ropa de trabajo, en tanto las labores en la quinta son permanentes. Cuando se

\footnotetext{
${ }^{26}$ Roberto Ringuelet et. al., Cuestiones Agrarias Regionales. Serie Estudios e Investigaciones de la Facultad de Humanidades y Ciencias de la Educación No. 6. (Bs. As: UNLP, 1991). Ringuelet comp., Espacio. María Alejandra Waisman, "Superando dualismos: trayectorias socio-productivas en el abordaje de las transformaciones en la estructura social hortícola platense". Revista Mundo Agrario, Vol: 12, No. 23 (2011). Matías García, "Proceso de acumulación de capital en campesinos. El caso de los horticultores bolivianos de Buenos Aires (Argentina)", Cuadernos de Desarrollo Rural, No.66 (2011). Matías García y Claudia Kebat. "Transformaciones en la horticultura platense. Una mirada a través de los censos". Revista Realidad Económica Vol: 237 (2008). Matías García y Julie Le Gall, "Reestructuraciones en la horticultura del AMBA: tiempos de boliviano". IV Congreso Argentino y Latinoamericano de Antropología Rural (2009) .
} 
ingresa a la quinta, es muy difícil reconocer a primera vista quién es patrón productor y quién peón. En este tipo de viviendas tienden a vivir los peones medieros, así como los peones migrantes del interior del país y de Latinoamérica.

A diferencia de los migrantes de ultramar que constituían familias numerosas, no es este el caso de los migrantes latinoamericanos, que tienden a conformar familias con menos integrantes. Además de tratarse de una migración joven de familias recientemente constituidas con hijos pequeños. Pero es común a ambos sujetos el hecho de que el trabajo en la quinta ocupe la totalidad de la fuerza de trabajo familiar. Varones, mujeres, adolescentes y niños se ocupan en diferentes labores dentro del proceso de producción.

Estas precarias condiciones de vida que se reseñaron para los migrantes recientes, fueron compartidas en sus inicios también por los migrantes ultramarinos. Pero estos últimos, en la medida que fueron ascendiendo socialmente, y si les fue posible adquirir la tierra en la que producían, hicieron una apuesta a la construcción de una vivienda de ladrillos. Los primeros migrantes de ultramar, entre los años 40 y 70 adquirieron la posesión del suelo y a partir de allí fueron construyendo sus casas. Sin embargo, las construcciones tienen un patrón bastante sencillo. Cuando se camina por las quintas rápidamente se pueden observar las casas familiares pintadas de blanco. Poseen en general dos habitaciones, una cocina comedor, un baño y algunas un pequeño living. Rodeadas de verde, con flores y frutales. Estas viviendas suelen tener agua potable y luz, aunque no siempre gas natural, siguen utilizando garrafa. Los patrones productores, en tanto dueños de la tierra, tienden a habitar este tipo de viviendas.

A diferencia de los inmigrantes de ultramar, que tuvieron la posibilidad de acceso a la compra de tierra, los migrantes latinoamericanos de los últimos 20 años no tuvieron hasta el momento esa posibilidad. Es por ello que la capacidad de construir sus viviendas de material se torna más complicada, ya que la misma queda en propiedad del dueño de la tierra una vez terminado el contrato de arriendo. Tienden entonces a invertir su dinero en bienes muebles como vehículos y directamente en la producción.

Tanto los patrones productores como los trabajadores han sido asiduos demandantes de los servicios públicos de salud y educación. Algunos de aquellos que lograron ascender socialmente utilizan servicios privados mandando a sus hijos, la tercera generación, a escuelas privadas, pudiendo además prescindir del trabajo de sus hijas e hijos en la producción. Pero para la mayoría, el hecho de haber podido acceder a servicios gratuitos de salud y educación primaria, secundaria y universitaria, aún con todas sus deficiencias, les permitió y les permite sobrevivir de una mejor manera sin que esto implicase grandes erogaciones de dinero ${ }^{27}$.

\footnotetext{
${ }^{27}$ Ringuelet et al, Cuestiones. Ringuelet comp. Espacio.
} 
La diferencia entre aquellos primeros migrantes y los contemporáneos radica en la posibilidad de acceso a la propiedad de la tierra, las diferencias en la necesidad de capital para iniciar la producción y el uso de las ganancias obtenidas. En este sentido, los migrantes gringos mejoraron sus condiciones de vida en función de su posibilidad de acceso a la tierra propia y al no haber necesitado tanto capital en los inicios para producir, pudieron invertir parte de sus ganancias en mejorar su hábitat inmediato. Más recientemente, siendo el acceso a la tierra muy difícil dado su alto costo, se deciden otras vías de inversión. Puede verse en las explotaciones, junto a casillas de madera muy precarias, grandes camionetas valuadas en cientos de miles de pesos, el contraste entre una vivienda extremadamente pobre y un vehículo de lujo es llamativo. También lo es el hecho de patrones productores que viven en las mismas condiciones que los trabajadores que emplean.

Resulta importante destacar aquí que cualquiera que fuere la clase social de los sujetos involucrados en la producción de hortalizas, sus condiciones-calidad de vida no superó ni supera las de cualquier trabajador asalariado promedio. Es decir que, observando la formación familiar, la posesión de tierra, vivienda, servicios elementales (luz, agua, gas), educación, salud, vestimenta y posesión de vehículo no se encontraron situaciones mejores que las del promedio de los trabajadores argentinos ocupados. Con esto no se quiere expresar que no haya contrastes dentro de las diferentes fracciones de la clase obrera respecto de sus condiciones de vida, sino que en promedio, los sujetos de la horticultura no las superaron. Pero lo más sugestivo es que, muy por el contrario, tendieron a vivir en peores condiciones. Tanto los patrones productores arrendatarios como los terratenientes y los asalariados tienden a unificarse en sus condiciones-calidad de vida, aún en sus diferencias de clase, estando muy por debajo de otros trabajadores. Incluso algunos investigadores asociaron las condiciones de vida tanto de pequeños patrones productores, peones medieros como de peones a situaciones de pobreza, en tanto entendían a esta como la incapacidad de acceder a la satisfacción de necesidades consideradas esenciales por una sociedad en un momento histórico determinado, la exclusión y desigualdad de acceso a bienes económicos y simbólicos, la vivencia de privaciones y el no alcance a un nivel de vida mínimo ${ }^{28}$.

\footnotetext{
${ }^{28}$ Attademo, Cambios en. Attademo, Lazos sociales. Silvia Attademo, "Participación de la mujer en la esfera del trabajo hortícola del Gran La Plata". V Congreso Argentino de Antropología Social (1997). Silvia Attademo, "El Trabajo Hortícola y la Situación de la Mujer en el Gran La Plata". Mujer, trabajo y pobreza en la Argentina, Ruth Sautu, Mercedes Di Virgilio y Gimena Ojeda (La plata: Edit. UNLP. 1999) 163-170. Silvia Attademo y María Cristina Salva, "Horticultura y condiciones de vida en un área subrural". X Congreso Mundial de Sociología Rural (2000).
} 


\section{Como actúan}

Los registros de conflictos y enfrentamientos en el sector hortícola datan de la década del 50. Los reclamos registrados desde esa época representan históricas problemáticas del sector hortícola en general. El paso del tiempo y las diferentes instancias organizativas dan cuenta de forma reiterada de las mismas dificultades. El proyecto inicial se proponía estudiar el conflicto en el sector hortícola platense a partir de 1950, sin embargo al momento de registrar los periódicos locales en la búsqueda de rastros de conflictividad los hallazgos fueron prácticamente nulos hasta la década del 80. Esto llevó a la necesidad de ampliar la indagación a nuevas fuentes. Fue así que a pesar de no haber noticias periodísticas en las cuales los horticultores aparecieran confrontando, sí se encontraron en otras fuentes datos de organización y cooperación entre ellos.

Una de estas iniciativas nació en tiempos del gobierno peronista, iniciándose hacia 1953 y viendo su final en 1963. Los patrones productores en esa oportunidad decidieron encarar la fundación de una cooperativa a la que llamaron "Cooperativa de Horticultores Eva Perón" (CHEP). Otro caso encontrado, previo a la década del 80, es el Congreso Nacional de Horticultura y Fruticultura que data de 1971, organizado por la Unión de Productores Agropecuarios de la República Argentina (UPARA, órgano gremial del Partido Comunista Argentino para el sector rural). Las actas del congreso dan cuenta de un análisis sistemático de las problemáticas que atravesaban al sector, así como de los reclamos expresados por el mismo y las iniciativas de resolución.

Ya iniciada la década del 80, los datos de conflicto y organización se vuelven más recurrentes, dando cuenta de cambios en el sector. La invisibilidad del conflicto hasta los años 80 puede comprenderse si se tiene en cuenta que la horticultura comercial propiamente dicha, es decir la producción orientada al mercado, tuvo su surgimiento mediando los años 40. El desarrollo de la misma recién alcanzó sus momentos más importantes a partir de los años 80, con la implementación de nuevas tecnologías productivas, que si bien habían surgido en los años 70, llegaron al cordón hortícola platense unos años más tarde. Puede decirse que hasta esos años, la producción de hortalizas no presentó grandes crisis desestabilizadoras, aunque sí se fueron esbozando algunas problemáticas que se desarrollarán con fuerza en los momentos de intensificación productiva a partir de la década del 80.

Los años que van desde 1994 aproximadamente, hasta el 2002, estuvieron atravesados por una profunda crisis estructural para los patrones productores y los trabajadores. Tal como se expresara en el acápite anterior, al haber cambiado las formas de producir y las relaciones laborales que le eran propias, complejizaron el panorama no sólo en lo que respecta a lo productivo sino también a las organizaciones gremiales que acompañaron estos cambios y sus reivindicaciones. Surgió una clara diferenciación hacia arriba y hacia abajo entre los patrones productores en lo referente a capitalización y productividad, lo cual trajo 
aparejado un aumento en la confrontación, con acciones que poseyeron una visibilidad notable y con un alto grado de violencia para los parámetros de lucha habituales en el sector. A través de diferentes métodos, como asambleas, declaraciones, movilizaciones y cortes de calles, los sujetos involucrados intentaron incidir en la forma en que las políticas del Estado municipal, provincial y nacional afectaban al sector. Otros denunciando la situación de precarización laboral en que se encontraban ${ }^{29}$.

A partir de la década del 80, la mayoría de las acciones de los sujetos hortícolas platenses las motorizó la Asociación de Productores Hortícolas de La Plata (APHLP) ${ }^{30}$ y la Asociación de Medieros y Afines (ASOMA) ${ }^{31}$, y a partir de 1998 apareció en escena también de manera destacada la Asociación de Quinteros de La Plata (AQLP) ${ }^{32}$ en representación de la fracción más empobrecida de productores. Estas tres organizaciones fueron las más visibles y activas, representando a patrones productores y peones medieros en la región platense. Tangencialmente entró en la confrontación la Unión Argentina de Trabajadores Rurales y Estibadores $\left(\right.$ UATRE) ${ }^{33}$ representando al sector de los peones

\footnotetext{
${ }^{29}$ Dado que los reclamos se repiten a lo largo del período bajo estudio se consignan aquí las diferentes fuentes de información consultadas a fin de no tener que reiterarlas cada vez que se desarrolla la información a partir de ellas recabada: Informe DIPBA, La Plata, 19/04, 22/04, 27/04, 03/05, 09/05, 10/05, 24/05, 31/05, 01/06, 21/06, 28/06, 27/07, 05/08, 31/08, 14/12/1994 y 17/05/1995. Diario Hoy, La Plata, 19/04 y 21/04, 1994. Diario El Día, La Plata, 22/01, 06/06, 26/06, 13/07, 16/07, 21/07, 28/09, 02/10, 16/12, 1999. Diario El Día, La Plata, 22/03, 18/03, 22/05, 23/05, 29/06, 23/08, 12/09, 13/09, 19/09, 20/09, 22/09, 29/09, 22/10, 24/10, 26/10, 28/12, 2000. Diario El Día, La Plata, 09/01, 11/01, 23/01, 24/01, 28/01, 30/01, 23/03, 30/01, 08/06, 18/07, 09/12, 2001. Diario El Día, La Plata, 20/01, 18/02, 20/03, 2002. ASOMA, Boletines Informativos y Plataforma a elecciones de la Lista Unidad. Actas de la APHLP, Asambleas anuales ordinarias y extraordinarias desde 25 de noviembre de 1983 (Acta fundacional) hasta el 4 de noviembre de 2002. Actas de la APHLP, Reuniones de la Comisión Directiva desde 2 de diciembre de 1983 (Acta nro.1) hasta 3 de noviembre de 1992 (Acta nro. 127).

${ }^{30}$ La Asociación de Productores Hortícolas de La Plata (APHLP) nació un 25 de noviembre de 1983. Con los aires renovadores de la democracia, y acompañando una oleada general de participación ciudadana, un grupo de 42 patrones productores hortícolas de La Plata, decidieron "bajo una necesidad imperiosa de unidad para fines comunes, organizarse conjuntamente con el resto del país. Para cooperar con las autoridades, los productores entre sí y con los trabajadores hortícolas que luchan contra las plagas, inclemencias del tiempo, precios y el mercado". APHLP Acta fundacional. La Plata, 25 de noviembre de 1983.

${ }^{31}$ La Asociación de Medieros y Afines (ASOMA), surgió en 1987, en la ciudad de La Plata, con 18 familias de medieros que decidieron organizarse. Desde sus inicios el Partido Comunista Revolucionario (PCR) estuvo presente en la organización, en coincidencia con su programa que se proponía trabajar con el sujeto más pobre del campo, en este caso peones medieros y trabajadores.

${ }^{32}$ La Asociación de Quinteros de La Plata (AQLP) apareció por primera vez en los registros periodísticos en el año 2000. Sin embargo su existencia se remontaba a 1998. Surgió como un agrupamiento de patrones productores de una de las zonas productivas más golpeadas por las políticas desarrolladas en los años 90: Gorina. Beatriz Nussbaumer, "La emergencia de acciones colectivas en el área hortícola bonaerense a partir de la década de los ochenta" (Tesis de posgrado/Maestría. Facultad de Agronomía, Universidad de Buenos Aires, 2000).

${ }^{33}$ La Unión Argentina de Trabajadores Rurales y Estibadores (UATRE) agremia a todos los trabajadores de la actividad agropecuaria, incluidos horticultores, trabajadores de empaque, carga y descarga en semilleros, centros de acopio, puertos y galpones y trabajadores de criaderos avícolas industriales.
} 
asalariados no importa cual fuere la forma de retribución de su trabajo (tarea, hora, día, mes o a destajo).

A partir de las fuentes consultadas puede decirse que, por un lado, en los registros aparecen confrontando sectores de la pequeña burguesía en sus dos fracciones más y menos empobrecida, es decir los patrones productores representados en la CHEP en la década del 50, el congreso de productores organizado por la UPARA a inicios de los años 70, la APHLP y la AQLP en los años 90. Llamativamente, el paso del tiempo no modificó sustancialmente sus reclamos aunque sí se volvieron más intensos y reiterados desde mediados de los años 90. Las acciones fueron dirigidas contra diversos sujetos e instituciones, la mayoría de ellas fueron orientadas contra lo que llamaban el "Estado" en sus diferentes "formas": gobierno y autoridades de gobierno. En ocasiones se conjugaron ataques y reclamos a varios de ellos (Gobierno Nacional, Provincial y Municipal). Otros sujetos de ataque fueron las entidades bancarias y entidades privadas: aseguradoras, empresas de servicios, importadoras de mercaderías de países limítrofes. Pero también se destacaron enfrentamientos hacia aspectos más estructurales: contra las condiciones que imponía el mercado capitalista de competencia indiscriminada, la crisis económica y específicamente en los años 90 contra las políticas de ajuste emanadas desde el Estado.

A lo largo del tiempo, en sus diferentes enfrentamiento manifestaron su descontento respecto de la competencia a la que eran expuestos en las relaciones del mercado capitalista, aduciendo que su pequeño tamaño y el hecho de producir mercancías no exportables los ponía en un lugar diferente que el resto de la producción agropecuaria nacional. También reclamaron la intervención activa del Estado para apaciguar las diferencias con los otros sectores productivos, solicitándole políticas de protección para el sector. Remarcaron el carácter altamente competitivo que tenían hacia el interior del sector, dado que todos producían los mismos bienes en la misma época del año para el mismo mercado. Este dato los llevó a competir entre ellos, desalentando la solidaridad y la cooperación, fomentando el individualismo.

Dichos enfrentamientos exponen los reclamos propios de la pequeña burguesía, y en el caso de los productores de hortalizas remiten a la escasa rentabilidad histórica de la producción, por momentos culpando de ello a la falta de políticas estatales y al abandono sufrido por parte del Estado. En los años del neoliberalismo también visualizaron la carencia de planes de desarrollo, la desidia de los organismos públicos y los políticos en la atención del buen funcionamiento de la economía, la falta de ayuda para planificar la producción, la falta de alternativas crediticias accesibles. Argumentando que eran productores de pequeño tamaño y de escala productiva pequeña, solicitaron la eliminación de las retenciones al IVA, la exención en los impuestos, la eliminación de Ingresos Brutos Agropecuarios, la reducción de aportes provisionales, la reducción de impuestos y tasas sobre la propiedad, la reducción de los impuestos a los insumos de importación para la producción hortícola. Ya desde la década del 70' pidieron que se impidiera el ingreso de mercadería de países limítrofes con 
la que debían competir, ser pasibles de subsidios, que se realizasen los controles fitosanitarios, que el Estado garantizara precios mínimos y políticas para evitar las intermediaciones parasitarias en la red de comercialización, mejoramiento de la red caminera, asistencia técnica para la aplicación de tecnologías modernas y ayuda para el desarrollo de la industria agroalimentaria local.

Por su parte los patrones productores más empobrecidos, si bien compartían el conjunto de reclamos con los horticultores de la región, destacaron fuertemente el acoso que sentían por parte de la UATRE para efectivizar la declaración legal de sus peones asalariados. Dieron cuenta en su discurso de ser un sector de patrones productores más pequeños y empobrecidos que no lograban, a diferencia de otros patrones productores más rentables, legalizar la mano de obra que contrataban sin poner en riesgo su reproducción social y productiva en el sector. Estos reclamos fueron llevados adelante por la AQLP.

Podemos observar entonces que en estos conflictos registrados aparece manifestándose por un lado la pequeña burguesía, burguesía empobrecida o pequeños patrones productores, quienes se caracterizan por ser propietarios de sus condiciones materiales de existencia que no venden su fuerza de trabajo, utilizan fuerza de trabajo ajena al grupo familiar de manera esporádica, cuya capacidad de acumulación, reinversión productiva de la riqueza y su capacidad de competencia con los capitalistas más grandes es muy limitada. Fracción de clase que, tal como muestran los registros del enfrentamiento, se encuentra en una situación de permanente diferenciación en dos capas: por un lado los pequeños patrones acomodados o pequeña burguesía acomodada, que explota un número más o menos considerable de obreros y asalariados y consigue realizar algún tipo de acumulación; por otro lado, los pequeños patrones pobres o pequeña burguesía pobre que apenas consigue sobrevivir sin realizar ninguna acumulación y cuya principal fuente de subsistencia es la pequeña propiedad ${ }^{34}$. En este sentido, los reclamos expuestos ponen de manifiesto que la pequeña burguesía es una clase en transición, en tendencia constante a la desaparición si bien el capitalismo tiende a su eliminación progresiva, siempre aparece de nuevo ${ }^{35}$. Esto significa que es una clase que se descompone y recompone constantemente con tendencia a su desaparición definitiva. No se trataría de una clase, sino de una situación, del sector que está en un proceso de formación, descomposición o recomposición hacia el proletariado o hacia la burguesía ${ }^{36}$. Tal como se ve expresado a partir de los enfrentamientos, estos pequeños propietarios son también expoliados por otros mecanismos diferentes a la forma salarial en que son expoliados los trabajadores, por ejemplo, el monopolio de demanda de

\footnotetext{
${ }^{34}$ AAVV, "Taller la Estructura Social en la Argentina", Programa de Investigación sobre el Movimiento de la Sociedad Argentina (PIMSA), Documento de Trabajo: 24 (2000). Vladimir Ilich Lenin, El desarrollo del capitalismo en Rusia. (Bs. As.: Ediciones Estudio. 1973). Lemmi, Las clases sociales en.

${ }^{35}$ Carlos Marx, El Dieciocho Brumario de Luis Bonaparte. (Bs. As: Edit. Need, 1998).

${ }^{36}$ Juan Carlos Marín, Los hechos armados. Un ejercicio posible (Buenos Aires: Edición del CICSO, 1984).
} 
las grandes empresas frente a la dispersión de la oferta de sus productos, los impuestos, el crédito, la usura, entre otros ${ }^{37}$.

Ambas fracciones de la burguesía confrontaron no sólo contra los capitalistas más grandes y su manejo de las políticas públicas y de mercado, sino también aparecen confrontando contra los trabajadores asalariados rurales representados en su gremio, la UATRE. Los patrones productores argumentaban, frente a la denuncia de no registrar legalmente a sus trabajadores y el cobro de multas por parte de la UATRE, que las cargas sociales eran muy altas para que pudieran afrontarlas los pequeños productores.

Pero, los peones medieros aparecieron con voz propia, ya que en su deseo de ascenso social reclamaron "la tierra para quien la trabaja", conjugado esto según la coyuntura, con reclamos a sus patrones en tanto obreros como el respeto de los derechos laborales más elementales. Enlazando esta doble condición del peón mediero, trabajador asalariado pero con deseos de ascenso social, apareció la ASOMA, organización gremial cuya línea osciló entre ambas identidades del sujeto "mediero": su condición obrera con sus deseos de ser burgués/poseer los medios de producción. Este sujeto representa el sector más empobrecido dentro de la cadena de producción hortícola, el hecho de estar completamente enajenados, tanto de los medios de producción como de parte de su libertad, los convierte en un sujeto particularmente sensible a las injusticias y permeable a la organización gremial $^{38}$. Denunciaron la problemática de la mano de obra ya que según sus registros el $90 \%$ de los trabajadores rurales de la zona no se encontraban registrados en el Ministerio de Trabajo, desarrollando su labor en pésimas condiciones de seguridad e higiene. Los integrantes de esta asociación se reconocían a sí mismos como campesinos pobres y medios, ya que la mayoría no poseía tierra propia pero trabajaba en tierras ajenas con la fuerza de trabajo de toda la familia y en condiciones muy precarias. Reivindicaban una reforma agraria integral y profunda y la creación de una "Junta Reguladora de Hortalizas" a partir de la cual se debía promover un precio mínimo sostén, fijando el precio de compra y venta. Proponían asimismo la creación de una Ley de mediería que reconociera a los peones medieros como trabajadores y pudieran otorgárseles aportes jubilatorios, obra social, vacaciones, salario familiar, etc. En los años más críticos para este sector empobrecido de la horticultura, los reclamos y denuncias estructurales fueron acompañados por otros donde se ponía el acento en las necesidades concretas e inmediatas de los peones medieros: alimentos, ropa, becas, útiles escolares, guardapolvos y calzados para poder estudiar, subsidios para los que quedaban desocupados en el sector, nylon y maderas para los invernaderos, semillas, herramientas para trabajar y precios compensatorios para su producción. Identificaron al Estado como representación de los intereses de los propietarios de tierras y reclamaron por la adquisición de la misma para quienes eran los genuinos trabajadores de las mismas,

\footnotetext{
${ }^{37}$ Iñigo Carrera, El concepto de.

38 Ringuelet et. al., Cuestiones. Roberto Benencia, "Formas de relación contractual y precarización del empleo en el mercado de trabajo hortícola" Revista de Estudios del Trabajo Vol: 12 (1996).
} 
combinando en sus reclamos las necesidades más inmediatas como comida, ropa y vivienda junto a la necesidad más estructural de repartir la tierra ${ }^{39}$.

Por otro, encontramos al sector de los trabajadores asalariados mediados por su gremio, la UATRE, cuyos reclamos consistieron en que se regularice la situación laboral ya que el trabajo no registrado en el sector hortícola es y ha sido muy alto, que se garantizasen el cumplimiento de los derechos laborales y que se pagasen las cargas sociales. Denunciaron que el sistema que los productores llamaban mediería era ilegal y que se lo utilizaba para encubrir una relación de trabajo asalariado evitando así su registro, evadiendo el pago de los aportes correspondientes y el cumplimiento de los derechos laborales para los asalariados. La forma primordial de accionar de la UATRE en la horticultura platense radicó en las inspecciones sorpresa a las quintas intentando detectar casos de trabajadores no registrados e incumplimiento de la legislación laboral. Pero el resultado de estas denuncias e inspecciones fue escaso, no logrando disminuir los altísimos niveles de trabajo no registrado en el sector ni que se respeten los derechos laborales en toda su magnitud (salario, jornada laboral, seguridad e higiene, vacaciones, etc.) o lograr mayores niveles de sindicalización.

El comienzo de la recesión en 1998, que culminó en la crisis del 2001 dio por resultado en el territorio hortícola platense la desaparición de un $40 \%$ de la superficie hortícola mientras que cesaron en su actividad o desaparecieron más de 100 explotaciones hortícolas, disminuyendo en 20.000 toneladas la producción y quedando desocupados de la actividad hortícola un $24 \%$ de los trabajadores (757 personas) ${ }^{40}$. A partir de la crisis que se desató hacia fines del año 2001 y que culminó con la devaluación de la moneda, los horticultores del Gran La Plata se vieron profundamente afectados. En sus reclamos los patrones productores sostuvieron que se encontraban al filo de la desaparición, responsabilizando de ello al Estado y exigiéndole la aplicación de soluciones que contribuyeran a regularizar la situación del sector. Pidieron que se encontrara la manera de hacer compatibles la cotización de los insumos en el exterior con los valores del mercado interno y que el Estado se posicionara como mediador ante proveedores y empresas de servicios para que estas aceptaran como medio de pago los bonos provinciales y nacionales. Por último, en vistas de resolución de la crisis, los años que van desde el 2002 en adelante, fueron de resurgir de la actividad. Con un panorama socio-productivo depurado de elementos no competitivos, aquellos patrones productores que lograron sobrevivir plantearon, en un nuevo contexto, un cambio en las relaciones de producción apareciendo elementos ya conocidos pero que desde hacía varios años estaban ausentes en este espacio productivo.

\footnotetext{
39 Ana Valtriani e Irene Velarde, "Historia y evolución de la Asociación de Medieros y Afines del Cordón Hortícola de La Plata”, Cuadernos de Desarrollo Rural, Vol: 44 (2000). Partido Comunista Revolucionario. Documentos aprobados por el 5to. Congreso del Partido Comunista Revolucionario, mayo de 1987. Tomo V. Entrevistados 20 y 24.

${ }^{40}$ García y Kebat.
} 
Los enfrentamientos se presentan como una sucesión de encuentros en los que se crean y destruyen relaciones sociales. La territorialidad social que se disputa en cada enfrentamiento, el conjunto de relaciones sociales que se ponen en juego, está construido por ciertas condiciones materiales, que son las mediaciones de relaciones sociales materiales. Se ve cómo a lo largo de los años, las diferentes clases involucradas en el conflicto intentaron sostener una territorialidad que el sistema capitalista en su tendencia a la competencia, concentración y centralización del capital amenazaba de forma permanente. Cada clase involucrada avanzó sobre las otras para defender su territorialidad amenazada. Así, ya desde los años 70 pero muy fuertemente en los años 90, frente al avance del capital y el aumento de la competencia entre patrones productores, estos descargaron los riesgos económicos que debían afrontar sobre los peones en forma de mediería. Hasta la década del 90 la crisis no se manifestó con profundidad en el sector, pero a partir de allí cada sector vulnerado intentó hacer recaer sobre los otros sectores las cargas del ajuste impuesto por la racionalidad capitalista. Los patrones productores tomaron crédito en los bancos y casas de agroinsumos y trasladaron los riesgos sobre los asalariados en forma de mediería (pagándoles a destajo). A su vez los peones medieros descargaron sobre sí mismos, sobre otros asalariados y su propia familia su precariedad. Fue el gremio de los trabajadores el que luchó por que la ley desconociera el pago a destajo como asimilable a la mediería y la efectivizara como tal, pero claro está, con magros resultados.

\section{Como piensan}

Se rastrea en el conflicto un dato que se repite a lo largo del tiempo: el nivel económico corporativo de la conciencia de los sujetos involucrados, no importa cual fuera su clase social; en tanto estos lograron ser solidarios con sus otros iguales sintiendo la unidad homogénea del grupo profesional y el deber de organizarse, destacándose en los momentos más críticos su conciencia de solidaridad de intereses entre todos los miembros del grupo social, aunque todavía en el campo meramente económico. Ya se planteaban la cuestión del Estado, pero sólo en el terreno de lograr una igualdad político-jurídica con los grupos dominantes, reivindicándose el derecho a participar en la legislación y en la administración y hasta de modificarla, de reformarla, pero en los cuadros fundamentales existentes.

Resulta importante aclarar que Gramsci, teórico referente en este estudio, entendía que el proceso de toma de conciencia no se da sólo en la clase trabajadora sino que es un proceso por el que atraviesan también las diferentes fracciones de la burguesía. Retomando los postulados de Marx, observó que no todas las fracciones de la burguesía poseen conciencia plena de su lugar en la producción y del funcionamiento total de las relaciones sociales. En este sentido, la mayoría del tiempo el burgués individual no comprende la totalidad del proceso de producción teniendo reclamos económico-corporativos, al igual que la clase trabajadora. El proceso de toma de conciencia de la totalidad capitalista y del rol que cada clase y fracción de clase cumplen en ella pasa tanto para la clase obrera como para la burguesía por diferentes estadios y momentos. 
Sin embargo en el caso aquí estudiado, ninguna de las clases involucradas logró alcanzar el momento más acabado de la conciencia, su último estadio, que en el sujeto obrero implica vislumbrar la necesidad de la destrucción del sistema capitalista para la construcción de uno nuevo, mientras que para la burguesía implica usar todas las armas a su alcance para la defensa estratégica del sistema que la sostiene como clase dominante ${ }^{41}$. Tanto los peones en su condición de asalariados mensualizados, jornaleros o a destajo, así como los patrones productores manifestaron una conciencia que no superaba los límites de la propia existencia dentro de las relaciones sociales capitalistas. Los pequeños burgueses, patrones productores reclamaron constantemente al Estado que interviniese para igualar la situación, para protegerlos frente a la competencia desigual en pos de convertirse en burgueses competitivos. Específicamente para el caso de los asalariados, la lectura que hacían de la realidad social y de su propia existencia no traspasó los límites impuestos por la hegemonía capitalista en tanto los reclamos expuestos muestran un sujeto que protestaba en tanto vendedor de su fuerza de trabajo, apelando al cumplimiento de la ley en su reconocimiento como tales y de ser incorporados al sistema en las mejores condiciones posibles. Incluso los peones medieros mostraban un entramado de su conciencia donde se identificaban con la conciencia burguesa.

Ahora bien, de dónde nace esta conciencia burguesa compartida, esta unidad de intereses entre los diferentes sujetos de la producción. Todos los migrantes que llegaron a la horticultura platense, no importa el momento histórico ni su origen nacional, arribaron con el objetivo de una mejora de su situación económica, en tanto la migración conllevaba la esperanza por una oportunidad de ascenso social, es decir, de "aburguesamiento" ${ }^{42}$. Este hecho, sus deseos de ser dueño de los medios de producción, de no trabajar para otros, puede ubicarse dentro de lo que Marx nombró como "las formas jurídicas, políticas, religiosas, artísticas o filosóficas, ideológicas" dentro de las cuales los sujetos en cuestión están inmersos y a partir de las cuales cobran conciencia de su condición y la dirimen ${ }^{43}$. Entonces, lo que puede observarse es que en el conjunto humano unido en la producción de hortalizas, existen dueños o no de los medios de producción, cuyas condiciones de vida han sido casi homogéneamente obreras pero su subjetividad ha sido plenamente burguesa. Esto es posible ya que la horticultura como nicho productivo históricamente ha posibilitado el ascenso social de algunos de los sujetos involucrados en la producción. Esto no quiere decir qué todos hayan ascendido socialmente pero sí que algunos han podido hacerlo, lo que

\footnotetext{
${ }^{41}$ Antonio Gramsci, “Análisis de las situaciones. Relaciones de fuerza”, en: Notas sobre Maquiavelo, sobre la política y sobre el Estado Moderno, Antonio Gramsci (Buenos Aires: Edit. Nueva Visión, 1990), 51 - 62. Marx, El Dieciocho Brumario. Marx, Miseria. Vladimir Lenin, ¿Qué hacer? Problemas candentes de nuestro movimiento (Buenos Aires: Edit. Anteo, 1974).

${ }^{42}$ Eduardo Sartelli, "Celeste, blanco y rojo. Democracia, nacionalismo y clase obrera en la crisis hegemónica (1912-1922)". Revista Razón y Revolución Nro. 2 (1996). Matías García, "Fuerza de trabajo en la horticultura de La Plata (Buenos Aires, Argentina). Razones y consecuencias de su competitividad". Revista Trabajo y Sociedad No. 22 (2014).

${ }^{43}$ Marx, Contribución.
} 
lleva a la construcción del deseo como algo posible, al desarrollo de la aspiración de "aburguesamiento".

La hegemonía burguesa ha construido una ideología según la cual para cumplir el anhelo de dejar de ser explotado se necesita reproducir la explotación en otros. Es así que puede verse cómo los primeros inmigrantes europeos al llegar a su condición de patrones productores sometieron a los nuevo migrantes del interior del país y de Latinoamérica a los mismos sufrimientos y explotación a los que ellos fueron sometidos. Y lo mismo sucedió con los migrantes latinoamericanos que lograron aburguesarse, quienes reprodujeron la situación con sus propios coterráneos recién llegados. Puede observase entonces una cadena de reproducción de la dominación tal como es planteada por las relaciones capitalistas. No importa si el conjunto "vive como peón" mientras su conciencia de la situación sea la de patrón, real o como una expresión de deseo. Tampoco importa el color de la piel, el origen étnico o nacional, ya que el deseo de ascenso social atraviesa a todas las culturas inmersas en las relaciones sociales capitalistas.

Esto puede explicarse a partir de entender, tal como se desarrolló teóricamente en acápites precedentes, que las clases no luchan clase contra clase en su expresión de "clase en sí" o "con respecto al capital", sino las que se enfrentan son fuerzas sociales, alianzas de clase tras objetivos comunes. Las clases sociales, en tanto conjuntos humanos se articulan en posiciones distintas en las relaciones de propiedad, luchan entre sí y al interior de sí, se alían entre sí y con fracciones de otras clases, la confrontación se da entre alianzas que constituyen fuerzas sociales ${ }^{44}$. Así puede verse como el proyecto que las unifica y que da la dirección a los enfrentamientos, la estrategia, la meta final que se quiere alcanzar en este caso: el ascenso social, el "sueño de ser burgués" y el abandono de la condición obrera, es la representación de los intereses de la clase dominante, de la burguesía, en tanto ella logró acaudillar, alinear tras de sí, de su proyecto a la clase trabajadora en su condición de migrante. Tal como fuera desplegado en acápites anteriores, la lucha teórica, la lucha por alinear tras de su proyecto a la mayor cantidad de aliados posibles de su misma clase o fracciones de otra clase, fue ganada por la burguesía en tanto organizadora de la sociedad y constructora del entramado ideológico que la sostiene.

Esto explica el motivo por el cual a pesar de haber vivido tanto los pequeños burgueses y los trabajadores, en condiciones obreras su conciencia de la situación ha sido otra. La asimilación en las condiciones-calidad de vida de los sujetos que permiten homologarlos "hacia abajo", es decir en su condición de vida obrera, aunque muchos de ellos

\footnotetext{
${ }^{44}$ Juan Carlos Marín, La noción de "polaridad" en los procesos de formación y realización del poder. Cuadernos de CICSO, Serie Teoría Nro. 8. (Bs. As: CICSO, 1981). Inés Izaguirre y Zulema Aristizábal, Luchas obreras 1973-1976. Los alineamientos de la clase obrera durante el gobierno peronista. Nuevas consideraciones teórico-metodológicas para e estudio de los conflictos obreros. Documentos de Trabajo Nro. 17 (Buenos Aires: Instituto de Investigaciones Gino Germani-UBA, 2000).
} 
objetivamente fueran dueños de sus condiciones materiales de existencia como se explicitado precedentemente, contrasta con su asimilación "hacia arriba" en la conciencia. Los pequeño burgueses, patrones productores, adquirieron conciencia de su situación de clase en su momento económico corporativo y reconocieron que su forma de vida era inferior a la que anhelaban, por ello reclamaron constantemente al Estado que interviniese para igualar la situación, para protegerlos frente a la competencia desigual en pos de convertirse en burgueses competitivos. También este hecho explica la aceptación por parte de los trabajadores de las condiciones de explotación bajo la forma de "mediería" o trabajo a destajo, involucrando al núcleo familiar completo y la totalidad del tiempo de su vida en las tareas productivas. Explica el motivo por el cual era tan engorrosa la posibilidad del gremio de trabajadores, UATRE, de lograr nuevas sindicalizaciones y reclamos. El gremio desconocía la "mediería" pero los trabajadores la aceptaban y la utilizaban como una estrategia de ascenso social.

Un último análisis conduce la reflexión al momento más amplio de la lucha, la constitución de fuerzas sociales. Se dijo que las clases luchan en tanto fuerzas sociales, y que estas últimas no están dadas a priori sino que se constituyen también en el enfrentamiento. Cuando se observan los enfrentamientos puede verse la constitución de las clases y al mismo tiempo la constitución de la fuerza social que están componiendo. Cómo se dilucida esto? Una vez más, viendo la estrategia, la meta que están intentando alcanzar. En este caso, cuando se rastrean los enfrentamientos se observa que la ideología que impulsó a los patrones productores por un lado y a los trabajadores por otro fue la de un Estado intervencionista y protector. Ellos consideraron que el mismo se encontraba por arriba de las clases sociales, mediando como un sujeto imparcial y vigilando la justa aplicación de la ley. Los sujetos de la horticultura no fueron liberales, nunca lo fueron por definición. Sólo a principios de los años 90, el sector más capitalizado de patrones productores, comulgó con algunos planteos del neoliberalismo pero acompañados de otros pedidos de intervención del Estado. A partir de mediados de los años 90 y sobre su final, finalmente impugnaron con toda su fuerza al régimen neoliberal capitalista, aunque no al capitalismo como sistema, repudiaron al Estado en su forma neoliberal y formaron parte de la fuerza social que en el 2001 cuestionó fuertemente la forma de dominación establecida. Tal como escribió Marx, "lo hacen pero no saben" "45 . Esta impugnación al capitalismo neoliberal de conjunto fue lo más lejos que llegaron en su lucha, manifestando el sesgo burgués y reformista de su conciencia.

\section{Conclusión: vivir como peón, pensar como patrón}

A lo largo del artículo pudo destacarse la centralidad de la condición de migrantes de los sujetos involucrados por sobre su nacionalidad o etnia de origen. Los sujetos que han llevado adelante este proceso a lo largo de toda su existencia, sin importar si fueron

\footnotetext{
${ }^{45}$ Marx, El Capital.
} 
italianos, españoles, portugueses, de las provincias del interior del país o latinoamericanos, poseen la característica de ser inmigrantes que en sus anhelos de ascenso social llegaron a La Plata para comenzar a trabajar como asalariados, en su forma de peón y peón mediero. Para muchos de ellos el paso al arrendamiento y luego a la propiedad de la tierra no les llevó más de 10 años. Este sujeto fue el encargado de consolidar un nicho económico de rasgos capitalistas. La producción y venta de hortalizas se ha caracterizado desde los años 40 en adelante por trabajar con mano de obra asalariada, por dueños de la tierra que reciben renta en tanto terratenientes y ganancia en tanto capitalistas. Sujetos que priorizan el ahorro para la reinversión productiva, inversión de capital para obtener más ganancias. Sujetos que se comportan como patrones una vez que ascienden en la escala social sin importar cual sea su origen étnico o nacional. Los trabajadores asalariados, al igual que en el pasado, aceptaron ingresar a la producción como peones medieros pagados a destajo, ya que al ser una actividad rentable económicamente les permitía un pequeño aunque progresivo ahorro si trabajaba el grupo familiar completo, esperanzados en poder usarlo en su propio ascenso social cuando se presentase la oportunidad.

Sin embargo, la crisis de fines de la década del 90, como toda crisis, funcionó como disciplinadora en varios sentidos. Por un lado disciplinamiento en un sentido productivo ya que aquellos sectores menos competitivos tendieron a la desaparición, los patrones productores dejaron de trabajar las tierras pero no se deshicieron de ellas pasando a ocuparse en otras labores como asalariados (choferes de micros y camiones, albañiles, carniceros, vendedores, etc.). Algunos peones medieros y trabajadores asalariados pasaron a formar parte del ejército de desocupados en busca de subsidios desde el Estado. Pero la crisis también fue disciplinadora en un sentido subjetivo, ya que la salida de la producción de los patrones productores dejó temerosos a los que sobrevivieron, generando reticencias a futuras inversiones. Para muchos de los patrones productores, descendientes de la primera oleada de inmigrantes, fue la pérdida de una trayectoria histórica en el sector que se remontaba a padres y abuelos.

Pudo observarse que todos los sujetos de la producción de hortalizas a través de sus organizaciones gremiales pasaron a componer la fuerza social que impugnó al capitalismo neoliberal hacia fines de 2001. Sus deseos frustrados de ascenso social conjugados con una condición de vida empobrecida los llevó a ser uno de los tantos defraudados con las promesas del neoliberalismo. Se llegó entonces al punto en el cual, a partir de 1994 en adelante aproximadamente, los diferentes sujetos de la producción hortícola se unificaron en su rechazo al capitalismo neoliberal en tanto éste los estaba desplazando hacia abajo en su condición de clase, pero no al sistema capitalista de conjunto.

Realizando un rastreo hacia atrás y poniendo la lupa en los reclamos pudo verse que a lo largo de toda la historia del sector los sujetos no traspasaron su conciencia económicocorporativa. Esto pudo explicarse a partir del contraste existente entre sus condiciones de vida objetivas y la forma en que esa condición pasaba por la conciencia. Se cuestionó en 
este artículo por qué si todos los sujetos de la horticultura han compartido y comparten similares condiciones de vida obrera, tal como se demostró en el acápite titulado "Cómo viven", no se encontraron masivamente reclamos desde esa posición de clase. Muy por el contrario, lo que demostró el registro del enfrentamiento tal como se vio en el acápite "Como actúan" es que los reclamos del sector de patrones productores, incluso en la crisis, y los de los peones medieros tendieron a identificarlos/unificarlos en su conciencia burguesa. Incluso los reclamos del gremio de los trabajadores asalariados mostraron un intento de incorporar a sus representados al sistema en tanto vendedores de fuerza de trabajo y el reclamo por hacer cumplir la ley que regula dentro del capitalismo las relaciones entre el capital y el trabajo.

Se comprobó entonces la existencia de fracciones de una burguesía empobrecida con condiciones de vida obrera y asalariados con condiciones de vida obrera, pero todos atravesados por una conciencia burguesa. Se estimó que este hecho nace motivado porque el sector hortícola se perpetúa como un espacio económico a partir del cual el ascenso social fue y es posible. Mientras existió y exista la posibilidad, y no sólo el deseo, de convertirse en capitalistas no surgieron ni surgirán otras formas de conciencia contrahegemónicas. Los horticultores platenses seguirán viviendo como peones pero pensando como patrones.

Recibido: 8 abril 2015 Aceptado: 19 julio 2015

\section{Obras citadas}

AAVV, "Taller la Estructura Social en la Argentina", Programa de Investigación sobre el Movimiento de la Sociedad Argentina (PIMSA), Documento de Trabajo: 24, 2000.

Archivos de la Asociación de Medieros y Afines, La Plata-Argentina.

Archivos de la Asociación de Productores Hortícolas de La Plata, La Plata-Argentina.

Attademo, Silvia y María Cristina Salva, "Horticultura y condiciones de vida en un área subrural". X Congreso Mundial de Sociología Rural (2000).

Attademo, Silvia, "El Trabajo Hortícola y la Situación de la Mujer en el Gran La Plata". Mujer, trabajo y pobreza en la Argentina, Sautu Ruth, Mercedes Di Virgilio y Gimena Ojeda (comp.) La plata: Edit. UNLP. 1999.163-170.

Attademo, Silvia, "Participación de la mujer en la esfera del trabajo hortícola del Gran La Plata”. V Congreso Argentino de Antropología Social (1997).

Attademo, Silvia. "Cambios en las condiciones de vida de los horticultores en la región subrural del Gran La Plata a fines de siglo". XXII Encuentro de la Latin American Studies Association (2000). 
Attademo, Silvia. "Lazos sociales y estrategias: ¿una opción para las familias hortícolas empobrecidas?". Revista Mundo Agrario. No. 17 (2008).

Benencia, Roberto. "El concepto de movilidad social en los estudios rurales", Estudios Rurales. Teorías, problemas y estrategias metodológicas. Giarraca, Norma (coord.). Buenos Aires: Edit. La Colmena. 1999.

Benencia, Roberto. "Formas de relación contractual y precarización del empleo en el mercado de trabajo hortícola". Revista de Estudios del Trabajo Vol: 12 (1996).

Diario El Día, La Plata, 1999-2002.

Diario Hoy, La Plata, 1994.

Archivos de la Dirección de Inteligencia de la Provincia de Buenos Aires, La PlataArgentina.

García, Matías y Claudia Kebat. "Transformaciones en la horticultura platense. Una mirada a través de los censos". Revista Realidad Económica Vol: 237 (2008).

García, Matías y Julie Le Gall, "Reestructuraciones en la horticultura del AMBA: tiempos de boliviano". IV Congreso Argentino y Latinoamericano de Antropología Rural (2009).

García, Matías, "Inicios, consolidación y diferenciación de la horticultura platense". Globalización y agricultura periurbana en la Argentina. Escenarios, recorridos y problemas. Svetlitza de Nemirovsky, Ada (coord.). Buenos Aires: Edit. FLACSO, 2010.

García, Matías, "Proceso de acumulación de capital en campesinos. El caso de los horticultores bolivianos de Buenos Aires (Argentina)", Cuadernos de Desarrollo Rural, No.66 (2011).

García, Matías. "Fuerza de trabajo en la horticultura de La Plata (Buenos Aires, Argentina). Razones y consecuencias de su competitividad". Revista Trabajo y Sociedad No. 22 (2014). Gramsci, Antonio. "Análisis de las situaciones. Relaciones de fuerza". En Notas sobre Maquiavelo, sobre la política y sobre el Estado Moderno, editado por Antonio Gramsci. Buenos Aires: Edit. Nueva Visión, 1990, 51 - 62.

Iñigo Carrera, Nicolás. "El concepto de clase obrera", Labour Again. Debates. Internacional Institute of Social History (2003).

Iñigo Carrera, Nicolás. La estrategia de la clase obrera 1936. Buenos Aires: Edit. La Rosa Blindada-PIMSA, 2004.

Izaguirre, Inés y Zulema Aristizábal, Luchas obreras 1973-1976. Los alineamientos de la clase obrera durante el gobierno peronista. Nuevas consideraciones teórico-metodológicas para e estudio de los conflictos obreros. Documentos de Trabajo Nro. 17. Buenos Aires: Instituto de Investigaciones Gino Germani-UBA, 2000.

Izaguirre, Inés. "Algunos ejes teórico-metodológicos en el estudio del conflicto social". Revista Argumentos, Vol: 1 (2002).

Lemmi, Soledad. "La institucionalización del conflicto en la horticultura platense. Un registro de los juicios en Tribunales del Trabajo en las décadas del 60 y 70 ". El conflicto agrario argentino. Sujetos, miradas y reflexiones. Muzlera José, Marina Poggi y Ximena Carreras Doallo (comp.) Buenos Aires: Edit. CICCUS. 2011. 
Lemmi, Soledad. "Las clases sociales en la horticultura platense. Ejercicio de teorización, historización y análisis empírico". Mundo Agrario, Revista de Estudios Rurales, Vol: 12 No. 23 (2011).

Lenin, Vladimir Ilich. El desarrollo del capitalismo en Rusia. Buenos Aires: Ediciones Estudio. 1973.

Lenin, Vladimir, ¿Qué hacer? Problemas candentes de nuestro movimiento. Buenos Aires: Edit. Anteo, 1974.

Marín, Juan Carlos. La noción de "polaridad" en los procesos de formación y realización del poder. Cuadernos de CICSO, Serie Teoría Nro. 8. Buenos Aires: CICSO, 1981.

Marín, Juan Carlos. Los hechos armados. Un ejercicio posible. Buenos Aires: Edición del CICSO, 1984.

Marx, Carlos y Federico Engels. Manifiesto del Partido Comunista. Buenos Aires: Edit. Anteo. 1997.

Marx, Carlos. Contribución a la Crítica de la Economía Política. México: Edit. Siglo XXI. 1990.

Marx, Carlos. El Capital. Buenos Aires: Edit. Siglo XXI, 2003.

Marx, Carlos. El Dieciocho Brumario de Luis Bonaparte. Buenos Aires: Edit. Need, 1998.

Marx, Carlos. Miseria de la Filosofía. Buenos Aires: Edit. Cartago, 1987.

Marx, Carlos. Trabajo asalariado y capital. Salario, precio y ganancia. Buenos Aires: Edit. Polémica, 1974.

Nussbaumer, Beatriz. "La emergencia de acciones colectivas en el área hortícola bonaerense a partir de la década de los ochenta" Tesis de posgrado/Maestría. Facultad de Agronomía, Universidad de Buenos Aires, 2000.

Partido Comunista Revolucionario. Documentos aprobados por el 5to. Congreso del Partido Comunista Revolucionario, mayo de 1987. Tomo V.

Pla, Alberto. "Apuntes para una discusión metodológica. Clases sociales o sectores populares. Pertinencia de las categorías analíticas de 'clase social' y 'clase obrera"'. Anuario de la Escuela de Historia de la Universidad Nacional de Rosario Vol: 14 (1989/90).

Pla, Alberto. "Trabajo productivo y trabajo improductivo, clases sociales y capitalismo". Anuario de la Escuela de Historia de la Universidad Nacional de Rosario Vol: 11 (1985).

Ringuelet Roberto et. al. Cuestiones Agrarias Regionales. Serie Estudios e Investigaciones de la Facultad de Humanidades y Ciencias de la Educación No. 6. Buenos Aires: UNLP, 1991.

Ringuelet, Roberto comp. Espacio tecnológico, población y reproducción social en el sector hortícola de La Plata. Revista No.39. Buenos Aires: UNLP, 2000.

Sartelli, Eduardo. "Celeste, blanco y rojo. Democracia, nacionalismo y clase obrera en la crisis hegemónica (1912-1922)”. Revista Razón y Revolución Nro. 2 (1996).

Thompson, Edward. La formación de la clase obrera en Inglaterra. Barcelona: Edit. Crítica, 1989.

Valtriani, Ana e Irene Velarde. "Historia y evolución de la Asociación de Medieros y Afines del Cordón Hortícola de La Plata". Cuadernos de Desarrollo Rural, Vol: 44 (2000). 
Vega, Mario. "Integración vertical y productos diferenciados", Boletín Hortícola, No. 23 (1999).

Viñas, Ismael. Tierra y clase obrera. Buenos Aires: Edit. Achával Solo, 1973.

Waisman, María Alejandra y María Florencia Rispoli. "Sembrando al sol. Algunas consideraciones antropológicas sobre el trabajo hortícola". V Jornadas de Sociología de la Universidad Nacional de La Plata (2008).

Waisman, María Alejandra, María Florencia Rispoli y Silvia Attademo. "Expectativas, opciones y proyectos: la dimensión subjetiva en la elección laboral de horticultores platenses". IX Congreso Argentino de Antropología Social "Fronteras de la Antropología" (2009).

Waisman, María Alejandra. "El debate sobre la persistencia de la producción familiar y sus implicancias en el abordaje de la horticultura". VI Jornadas de Sociología de la Universidad Nacional de La Plata (2010).

Waisman, María Alejandra. "Superando dualismos: trayectorias socio-productivas en el abordaje de las transformaciones en la estructura social hortícola platense". Revista Mundo Agrario, Vol: 12, No. 23 (2011). 